\title{
Modelling Price Determination in South Africa
}

\author{
Elna Moolman ${ }^{1}$ and Charlotte du Toit
}

Department of Economics, University of Pretoria

\begin{abstract}
South Africa has been faced with high inflation rates since the early 1970s. Despite continued monetary discipline the inflation target has not yet been met, highlighting South Africa's price-vulnerability as a small open emerging economy and raising questions about the efficiency of monetary policy. The objectives of this paper are: (i) to analyse the influence of monetary policy on inflation in the small open emerging economy of South Africa, (ii) to highlight the channels other than monetary policy through which inflation can be influenced (iii) to analyse the influence of international prices and the exchange rate on inflation, (iv) to determine the role of the labour market on inflation, especially through wage-push dynamics and (v) to determine the role of demand-pull factors on inflation.
\end{abstract}

JEL E31, 37, 52

\section{INTRODUCTION}

South Africa has been faced with relatively high inflation rates since the early 1970s, which has been addressed through a very disciplined monetary policy. In 1989 the central bank adopted its current mission of protecting the internal and external value of the rand and it was made clear that monetary policy would be focused on curbing inflation. In 2000 the Reserve Bank took this a step further when it adopted an inflation-targeting regime, with a target range for average CPIX inflation ${ }^{2}$ of between three and six per cent for 2002 and 2003 and between three and five per cent for 2004 and $2005^{3}$. The CPIX inflation was pegged back slowly from levels above 8 per cent in the middle of 2000 and dropped to levels within the target range in September and October 2001 when it was 5.8 and 5.9 per cent respectively. However, despite a continued disciplined monetary policy, CPIX inflation has not been within the target range since then ${ }^{4}$. In fact, CPIX escalated to levels of 12 per cent by the end of 2002. The failure to meet the target has been attributed to external shocks such as the substantial depreciation of the rand in 2001, but has also emphasised South Africa's price-vulnerability as a small open economy and raised questions about the efficiency of monetary policy. 
In this study, the determination of prices in South Africa is analysed in order to determine the impact of various factors on inflation as well as to explore alternative vehicles for addressing South Africa's renewed high inflation rate. A model for the determination of consumer and production prices in South Africa is developed and estimated. A system of equations for price determination is estimated, not only making a distinction between the determination of consumer and production prices, but also modeling the linkages between them. Such a system is able to capture more of the dynamics in the process of price determination than single equation inflation models such as Akinboade, Niedermeier and Siebrits (2002). This will make an important contribution to the debate of whether, and to what extent, policy makers can influence inflation with different policy instruments, especially in the face of exogenous shocks. The objectives of this paper are: (i) to analyse the influence of monetary policy on inflation, (ii) to suggest alternative policy instruments with which inflation can be addressed, (iii) to analyse the influence of foreign prices and the exchange rate on inflation, (iv) to determine the role of the labour market on inflation, especially through wage-push dynamics and (v) to determine the role of demand-pull factors on inflation.

This estimated price system forms part of the neoclassical supply-side of the macroeconomic model of the University of Pretoria. For purposes of consistency, the Layard-Nickell approach, utilised in the macroeconomic model to model wages and employment, is employed. The paper is organised as follows: The next section describes the course of inflation in South Africa. Section three summarises the theoretical background, while the estimation results are presented in section four. Sections five and six provide some policy implications and conclusions from the study respectively.

\section{INFLATION IN SOUTH AFRICA}

South Africa experienced low levels of inflation until the early 1970s, but the oil price shock in 1973 led to higher inflation both worldwide and domestically and consequently inflation became a policy priority in South Africa. During his tenure, Dr De Jongh (Reserve Bank Governor from 1967 to 1980) implemented a series of additional direct controls such as a ceiling on advances, deposit rate controls, exchange controls, import deposits and some direct consumer credit controls in an effort to contain the persistent increases in money supply and the inflationary tendency. 
The monetary controls of the 1960s and 1970s gave way in the 1980s to a general recognition of the need to abolish as many restrictions as possible in a shift towards market-oriented policy. The growing influence of the policy approach of the Thatcher government in the United Kingdom and the Reagan administration in the United States in the 1980s, caused a definite shift across the globe in favour of market-oriented policy measures. This shift in policy approach was further encouraged by the liberalisation of international financial markets. South Africa followed suit by adopting a more market-oriented approach. The trend gained momentum after the report of the De Kock Commission in 1984/1985. In line with the international trend at the time, the Reserve Bank, under Dr De Kock ${ }^{5}$, started to align its policies with developments in markets, rather than to try to force markets in a pre-determined direction. More emphasis was placed on using interest rate adjustments rather than direct credit extension restrictions.

This was undoubtedly a very difficult decade in the history of the Reserve Bank, operating with limited indirect intervention in the face of widespread international hostility and growing resistance, as a result of the economic and racial policies of the government at the time. After President PW Botha's Rubicon speech in 1985, international sanctions and the debt standstill agreement ${ }^{6}$ were introduced against South Africa. This led to an immediate outflow of substantial amounts of capital, with a total net capital outflow of R4 359 million during 1985. In an attempt to simultaneously discourage capital outflows and to attract foreign capital, persistently high interest rates were kept high during the period of international isolation (Botha, 1997; Fourie et al., 1999: 314).

Although the monetary policy approach still remained market-oriented in the 1990s (with Dr. Stals as governor of the Reserve Bank), this period was characterised by dramatic socio-political changes. After the first democratic election in 1994, political barriers were dropped. The abolition of sanctions against South Africa and the scrapping of exchange controls on foreigners by the South African government exposed South Africa to world financial market movements. Since 1994 in particular, South Africa has adopted a clearly defined policy of actively participating in the process of financial globalisation and has implemented a number of economic policies to facilitate the process of its participation in globalisation (Stals, 1999). 
During the 1990s inflation rates declined steadily from 15,3 per cent in 1991 to 5,2 per cent in 1999. Following countries such as New Zealand, Canada, Sweden and the United Kingdom, South Africa adopted an inflation-targeting regime in February 2000. The initial target range for average CPIX inflation, was three to six per cent for 2002 and 2003 and between three and five per cent for 2004 and 2005. The CPIX inflation was pegged back slowly from levels above 8 per cent in mid-2000 and dropped to levels within the target range in September and October 2001 when it was 5.8 and 5.9 per cent respectively. However, following the dramatic depreciation of the rand from R8,63/US\$ in September 2001 to R11,61/US\$ in January 2002, CPIX escalated to levels of 12 per cent by the end of 2002. Despite continued disciplined monetary policy and a cumulative increase in the repo rate of 400 basis points, CPIX inflation has not been within the target range since October 2001. The Governor of the Reserve Bank and the Minister of Finance conceded that the inflation target would not be attained in 2002 or 2003 and subsequently amended the target for 2004 to three to six per cent. The failure to meet the target has emphasised South Africa's price-vulnerability as a small open economy and has also raised questions about the efficiency of monetary policy.

\section{THEORETICAL FRAMEWORK}

In a neoclassical profit-maximizing framework with imperfect market competition, such as the one suggested by Layard and Nickell (1985, 1986; Nickell, 1988), firms set prices as a mark-up on the marginal cost of production, proxied by average or unit costs (Burda \& Wyplosz, 1993: 256):

$$
P^{p}=m * A C \quad \text { where } m=\frac{1}{1-1 / \eta}>1 ; \quad m^{\prime} \geq 0
$$

with $P^{p}$ production prices, $m$ the price mark-up, $A C$ average or unit cost of production and $\eta$ price elasticity of demand.

The mark-up $(m)$ depends on the sensitivity of the market to price changes, measured by the price elasticity of demand. As it is natural to think of $m$ as being influenced by the short-run demand position, it may be specified in terms of a demand pressure variable, such as expected demand relative to normal output (Nickell, 1988):

$$
m=m\left(Y^{e d} / Y^{*}\right) \text {. }
$$


Although the cost of production includes both labour and capital costs, it is standard practice to base a model of price-setting on normal unit (average) costs, where "normal" in this context refers to labour costs only, excluding the cost of capital".

Assuming normal unit costs (similar to Layard \& Nickell), average cost of production may be specified in terms of (1) changes in nominal wage rates relative to labour productivity, (2) cyclical demand pressures such as deviations in actual unemployment rates from the equilibrium rate of unemployment, rates of capacity utilisation, etc. and (3) exogenous supply shocks (Burda \& Wyplosz, 1993: 243-48).

Layard and Nickell go a step further by expanding the price equation to incorporate expected competitors' prices, yielding a price-setting equation of the form:

$$
P^{p} / W=h\left(P^{p} / P^{e}\right) m\left(Y^{e d} / Y^{*}\right) g\left(Y^{*} / \alpha L\right)
$$

where $W$ is nominal wages inclusive of employers' labour taxes, $P^{p} / P^{e}$ is production (value-added) relative to expected prices and $Y^{*} / \alpha L$ is the normal labour productivity (Nickell, 1988: 203-4).

Consumer prices $\left(P^{c}\right)$, which are directly related to production prices, may now be specified as:

$$
P^{C}=f\left(P^{p}, t^{i}, P^{m}\right)
$$

where $t^{i}$ is indirect taxes and $P^{m}$ import prices on consumption goods.

\section{EMPIRICAL ESTIMATION}

\subsection{Model specification}

Following the Layard-Nickell (1985 and 1986) framework, mark-up pricing is used as the basis to model price-setting behavior in South Africa. Whereas Layard and Nickell assume normal unit costs, this study has opted for an approach where unit capital costs are also included in the price equation. Longrun production or value-added prices $P^{p}$ are therefore specified and estimated as: 


$$
\begin{gathered}
P^{p}=f((W / \text { product }), r) \\
+\quad+
\end{gathered}
$$

where $\mathrm{W}$ is the nominal wage rate, product is labour productivity and $\mathrm{r}$ is the nominal user-cost-of-capital. A measure for capacity utilisation $(\mathrm{cu})$ is included in the short-run specification of the model to capture potential demand pressures.

Based on the theoretical exposition in the previous section, consumer prices $\left(P^{c}\right)$ are specified as:

$$
P^{C}=f\left(P^{p}, P^{m}, G D E / G D P\right)
$$

where $P^{P}$ is the domestic production price index and $P^{m}$ the price level of imported goods. Excess demand, GDE/GDP (gross domestic expenditure relative to gross domestic production in nominal terms), captures any demand pressure effects in the economy. This variable is included in the short-run equation of the consumer price index.

\subsection{The data}

Annual data for the period 1975 to 2000 was used in the estimations. Table 1 provides a list of the variables used in the estimation. The primary data was obtained from the South African Reserve Bank. Sections 4.2.1 to 4.2.3 expose the construction of the user cost of capital (ucc), capacity utilisation (cu) and the international positional index (intl).

\section{Table 1 Variable list}

\begin{tabular}{|l|l|}
\hline Variable & \multicolumn{1}{|c|}{ Explanation } \\
\hline & \\
\hline ucc & User cost of capital \\
\hline Cpi & Consumer price index \\
\hline Ppi & Production price index \\
\hline Wprod & Wage productivity \\
\hline Pz & Price of imports \\
\hline cu & Capacity utilisation \\
\hline ExDem & Excess demand \\
\hline Intl & International position \\
\hline R\$ & Rand-US\$ exchange rate \\
\hline
\end{tabular}




\subsubsection{User cost of capital}

The neoclassical theory of capital accumulation is formulated in two alternative, yet equivalent ways. First, the firm may accumulate capital to supply the service to itself. The objective of the firm is to maximize its value, subject to its technical limitations. Secondly, the firm may rent the assets in order to obtain a capital service. In this case, the objective of the firm is to maximize its current profit, defined as gross revenue less the cost of inputs less the rental value of capital. The rental can be calculated from the relationship between the price of new capital goods and the discounted value of future services received from these goods (Jorgenson, 1993: 4).

According to Jorgenson (1993), in the absence of direct taxes, this relationship takes the form:

$$
\mathrm{q}_{\mathrm{t}}=\int \mathrm{e}^{(-\mathrm{r})(\mathrm{s}-\mathrm{t}) \mathrm{c}(\mathrm{s})-\delta(\theta-\mathrm{t})} \mathrm{ds}
$$

where $r$ is the discount rate, $q$ the price of capital goods, $c$ the cost of capital services and $\delta$ the rate of replacement (depreciation). The time of acquisition is given by $t$ and time $s$ is the time during which capital services are supplied (Jorgenson 1993: 4). Differentiating this with respect to $\mathrm{t}$ gives $\mathrm{c}=\mathrm{q}(\mathrm{r}+\delta)-\mathrm{q}$, which is the rental price of capital services supplied by the firm to itself. Under static expectations about the price of investment goods, the rental price reduces to $\mathrm{c}=\mathrm{q}(\mathrm{r}+\delta$. $)$.

To extend the formula to allow for taxation, Jorgenson (1993) defines a depreciation formula $D(s)$ to calculate the proportion of the original cost of an asset of age $s$, which may be deducted from taxes. Jorgenson also assumes a tax credit $k$ that may be deducted from investment expenditure. If the tax rate is constant over time at rate $u$, the equality between the price of investment goods and the discounted value of capital services is:

$$
\mathrm{q}_{\mathrm{t}}=\int \mathrm{e}^{(\mathrm{t})(\mathrm{s}-\mathrm{t})}\left[(1-\mathrm{u}) \mathrm{c}(\mathrm{s}) \mathrm{e}^{-\delta(\theta-\mathrm{t})}+\mathrm{u}(1-\mathrm{k}) \mathrm{q}(\mathrm{t}) \mathrm{D}(\mathrm{s})\right] \mathrm{ds}+\mathrm{k} \mathrm{q}_{\mathrm{t}} \text {. }
$$

Allowing the present value of depreciation on one rand's worth of investment to be denoted by $z$ gives:

$z=\int e^{-r s} D(s) d s$.

The rental value of capital under static expectations then becomes: 


$$
\mathrm{c}=\mathrm{q}(\mathrm{r}+\delta) \times \frac{(1-\mathrm{k})(1-\mathrm{uz})}{(1-\mathrm{u})} .
$$

The effect of tax policy on investment behaviour enters the investment function through the rental value of capital. This results in a change in the desired level of capital. Such a change leads to net investment (or disinvestment), increasing (or decreasing) capital stock to its new desired level (Jorgenson 1993: 4).

The user-cost-of-capital ( $r$ ) in nominal or current price terms can be expressed as:

$r=$ price of capital $\left[\frac{\text { interest rate })+(\text { rate depreciation })}{1-\text { tax ratio }}\right]$.

This measure for user-cost-of-capital, therefore, combines four effects (costs): The first relates to an opportunity cost to invest and, based on the long run nature of investment, is approximated by the yield on long-term government bonds. Second, fluctuations in the price of capital may lead to losses or gains for a firm when it sells its capital at the end of a period. A capital gain (loss) would reduce (increase) the user-cost-of-capital. A third cost for the owner of capital stems from the depreciation of capital, while the fourth component is taxes, resulting in a difference between the pre-tax and after-tax rates of return on capital.

\subsubsection{Capacity utilisation}

Capacity utilisation, or the output gap, is the ratio between the actual and potential output of the economy. Output in general is determined by the quantity and quality of the various factors of production and their productivity. Potential output is an indication of the aggregate supply capabilities of the economy and embodies information about developments in the stock of capital, the labour force and technical change. The actual level of output on the other hand, is also influenced by the demand for goods and services. Deviations between the potential and actual levels of output, designated as the output gap, thus provide a measure of the capacity utilisation of the economy and to the extent that demand factors are incorporated, it also gives a measure of relative supply and demand in the economy at a particular time. However, modeling capacity utilisation is a complicated matter, since different concepts of potential output have been proposed in the literature and a wide variety of empirical methods are used to measure potential output, ranging from time-series and trend-type analyses to production function-based methodologies. 
Two measurements of potential output have been used in the literature. First, measures of potential output that are structural and depend on a production function framework, incorporating information concerning the capital stock, working population, trend participation rates, structural unemployment and factor productivity developments. Specific attention may also be given to the sustainability of non-inflationary growth associated with the labour market, in which case information about both actual rates and underlying natural rates of unemployment is utilised (i.e. the non-accelerating wage rate of unemployment, or NAWRU). A second set of measures is derived by applying time-series analysis and methods to actual developments in real GDP. Though parsimonious in the use of information, these methods are mechanical and have difficulty in dealing with frequent structural changes. They therefore require ad hoc judgements about the current cycle in order to keep the results within reasonable bounds.

In this study, potential output is defined as the maximum level of output that is consistent with stable inflation. Capacity utilisation is, therefore, defined as the ratio between actual production (production function-based) and potential output, incorporating the role of the non-accelerating wage rate of unemployment (NAWRU). Following the approach of the $\mathrm{OECD}^{8}$, the estimation of potential output for South Africa is based on a structural production-function relationship, with the maximum level of output consistent with stable inflation. The level of unemployment and its associated nonaccelerating wage rate are incorporated in the estimation of potential employment. The measure of capacity utilisation used in this paper was adopted from Du Toit and Moolman (2003), who provides a detailed exposition of the estimation of this measure of capacity utilisation for South Africa.

\subsubsection{International positional index}

Du Toit (1999) developed an index reflecting the international position of South Africa. This index is a weighted average of the exchange rate, South Africa's share in world trade, direct foreign investment relative to gross domestic investment, indirect foreign investment relative to gross domestic investment and South Africa's international competitiveness (measured by domestic export prices relative to world export prices). 


\subsection{Empirical results}

Johansen's cointegration technique was applied to determine the number of cointegrating vectors and to estimate these vectors. Table 2 gives the results of the eigenvalue test, which indicate that the equation is indeed cointegrated and that there are two cointegration vectors which are normalised to be cointegrating vectors for the consumer price index (cpi) and the production price index (ppi). The order of the VAR was determined on the basis of the Likelihood and the Akaike and Schwartz-Bayesian criteria. The cointegration results are reported in tables 3 and 4 .

The likelihood ratio did not reject the restrictions of the system. This means that the long run equilibrium level of consumer prices in South Africa is determined by domestic production prices as well as the prices of imported goods. Production prices, on the other hand, are determined by the user cost of capital and wage productivity ${ }^{9}$.

Figure 1 Consumer and production price inflation, 1971-2000

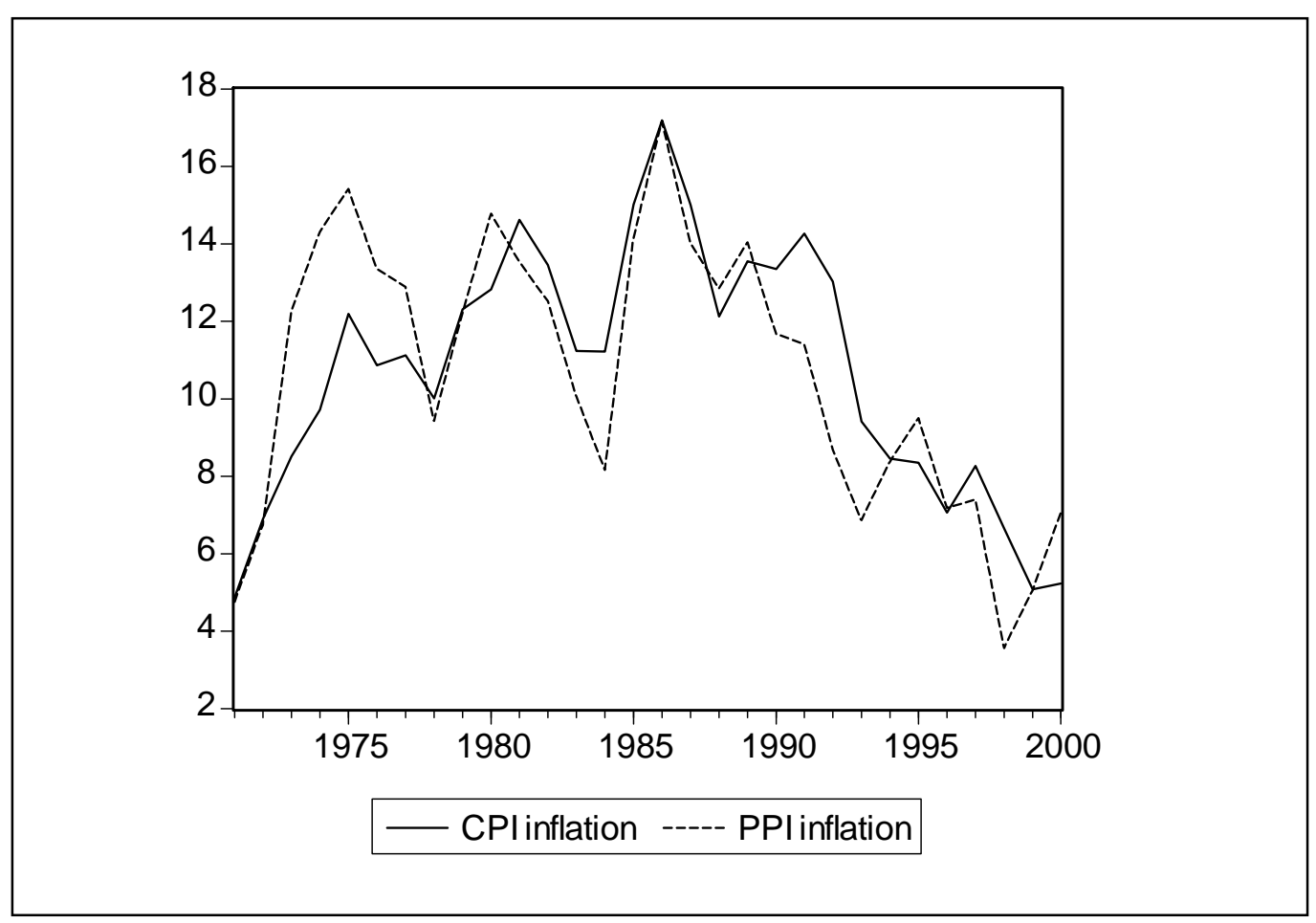




\section{Table 2 Eigenvalue test for cointegration}

\begin{tabular}{|c|c|c|c|c|}
\hline \multicolumn{5}{|c|}{$\begin{array}{l}\text { Cointegration LR test based on trace of tl } \\
\text { Order of VAR = } 2 \\
\text { List of Eigenvalue in descending order: }\end{array}$} \\
\hline Null & Alternative & Statistic & $\begin{array}{c}95 \% \text { critical } \\
\text { value }\end{array}$ & $\begin{array}{c}90 \% \text { critical } \\
\text { value }\end{array}$ \\
\hline $\mathrm{r}=0$ & $\mathrm{r}>=1$ & 76.39* & 70.49 & 66.23 \\
\hline $\mathrm{r}<=1$ & $\mathrm{r}=2$ & 48.96* & 48.88 & 45.70 \\
\hline $\mathrm{r}<=2$ & $r=3$ & 27.36 & 31.54 & 28.78 \\
\hline $\mathrm{r}<=3$ & $\mathrm{r}=4$ & 15.21 & 17.86 & 15.75 \\
\hline $\mathrm{r}<=4$ & $\mathrm{r}=5$ & 6.85 & 8.07 & 6.5 \\
\hline
\end{tabular}

* $\quad$ Reject null hypothesis on $5 \%$ level of significance

After the long-run cointegration relationships have been determined, the error correction models (ECM) were estimated in order to capture the short-run or dynamic adjustment process towards the long-run equilibrium. It incorporates the equilibrium error (residual terms) estimated from the long-run equilibrium relationship. The estimation results of the ECMs are reported in tables 5 and 6.

\section{Table 3 Cointegration equation: CPI}

\begin{tabular}{|c|c|c|c|}
\hline \multicolumn{4}{|c|}{ Dependent variable: Log(CPI) } \\
\hline \multicolumn{4}{|c|}{ Method: Maximum likelihood } \\
\hline \multicolumn{4}{|c|}{ Order of VAR: 2} \\
\hline \multicolumn{2}{|l|}{ Variable } & \multicolumn{2}{|c|}{ Coefficient } \\
\hline \multicolumn{2}{|l|}{$\log (\mathrm{PPI})$} & \multicolumn{2}{|c|}{0.70} \\
\hline \multicolumn{2}{|l|}{$\log (\mathrm{PZ})$} & \multicolumn{2}{|c|}{0.30} \\
\hline $\begin{array}{l}\text { LL: exactly identifying } \\
\text { restrictions }\end{array}$ & 307.06 & $\begin{array}{l}\mathrm{LR} \chi^{2}(1) \\
\text { p-value(LR) }\end{array}$ & $\begin{array}{l}13.06 \\
0.011\end{array}$ \\
\hline $\begin{array}{l}\text { LL: over-identifying } \\
\text { restrictions }\end{array}$ & 300.53 & $\begin{array}{l}\text { Degrees of } \\
\text { freedom }\end{array}$ & 4 \\
\hline
\end{tabular}




\section{Table 4 Cointegration equation: PPI}

\begin{tabular}{|c|c|c|c|}
\hline \multicolumn{4}{|c|}{ Dependent Variable: $\log (\mathrm{PPI})$} \\
\hline \multicolumn{4}{|c|}{ Method: Maximum likelihood } \\
\hline \multicolumn{4}{|l|}{ Order of VAR: 2} \\
\hline \multicolumn{2}{|l|}{ Variable } & \multicolumn{2}{|c|}{ Coefficient } \\
\hline \multicolumn{2}{|l|}{ Log(UCC) } & \multicolumn{2}{|c|}{0.680} \\
\hline \multicolumn{2}{|l|}{ Log(WPROD) } & \multicolumn{2}{|c|}{0.923} \\
\hline $\begin{array}{l}\text { LL: exactly identifying } \\
\text { restrictions }\end{array}$ & 307.06 & $\begin{array}{l}\text { LR } \chi^{2}(1) \\
\text { p-value(LR) }\end{array}$ & $\begin{array}{l}13.06 \\
0.011\end{array}$ \\
\hline $\begin{array}{l}\text { LL: over-identifying } \\
\text { restrictions }\end{array}$ & 300.53 & $\begin{array}{l}\text { Degrees of } \\
\text { freedom }\end{array}$ & 4 \\
\hline
\end{tabular}

\section{Table 5 Error correction model: CPI}

\begin{tabular}{|c|c|c|c|c|c|}
\hline \multicolumn{6}{|c|}{ Dependent variable: $\Delta \log (\mathrm{CPI})$} \\
\hline \multicolumn{6}{|c|}{ Method: Least squares } \\
\hline Variable & Coefficient & Std. Error & \multicolumn{2}{|c|}{ t-Statistic } & p-value \\
\hline C & 0.021747 & 0.012005 & \multicolumn{2}{|c|}{1.811431} & 0.0844 \\
\hline RES_CPI(-1) & -0.046091 & 0.012264 & \multicolumn{2}{|c|}{-3.758164} & 0.0012 \\
\hline$\Delta \log (\mathrm{CPI}(-1))$ & 0.531621 & 0.128918 & \multicolumn{2}{|c|}{4.123725} & 0.0005 \\
\hline $\log (\operatorname{EXDEM}(-1))$ & -0.256659 & 0.091861 & \multicolumn{2}{|c|}{-2.794005} & 0.0109 \\
\hline$\Delta \mathrm{LOG}(\mathrm{R} \$(-1))$ & -0.072678 & 0.025977 & \multicolumn{2}{|c|}{-2.797796} & 0.0108 \\
\hline R-squared & 0.838259 & \multicolumn{2}{|c|}{ F-statistic } & \multicolumn{2}{|c|}{27.20921} \\
\hline \begin{tabular}{|l|} 
Adjusted \\
squared
\end{tabular} & 0.807451 & \multicolumn{2}{|c|}{ Prob(F-statistic) } & \multicolumn{2}{|c|}{0.000000} \\
\hline S.E. of regression & 0.013876 & & & & \\
\hline
\end{tabular}


Table 6 Error correction model: PPI

\begin{tabular}{|c|c|c|c|c|}
\hline \multicolumn{5}{|c|}{ Dependent variable: $\Delta \log (\mathrm{PPI})$} \\
\hline \multicolumn{5}{|c|}{ Method: Least squares } \\
\hline Variable & Coefficient & Std. error & t-Statistic & p-value \\
\hline C & -1.984344 & 0.855283 & -2.320102 & 0.0339 \\
\hline RES_PPI(-1) & -0.115484 & 0.045191 & $-2.55544 \mathrm{C}$ & 0.0212 \\
\hline$\Delta \log (\operatorname{INTL}(-2))$ & -0.097033 & 0.040208 & -2.413251 & 0.0282 \\
\hline$\Delta \log (\mathrm{WPROD})$ & 0.249052 & 0.121367 & 2.052061 & 0.0569 \\
\hline $\log (\mathrm{CU})$ & 0.818430 & 0.178144 & 4.594216 & 0.0003 \\
\hline$\Delta \log (\mathrm{PPI}(-1))$ & 0.501642 & 0.158626 & 3.162420 & 0.0060 \\
\hline $\log (\mathrm{CU}(-2))$ & -0.397681 & 0.202914 & -1.959851 & 0.0677 \\
\hline R-squared & 0.841135 & \multicolumn{2}{|c|}{ F-statistic } & 14.11906 \\
\hline \begin{tabular}{|l} 
Adjusted R- \\
squared
\end{tabular} & 0.781560 & \multicolumn{2}{|c|}{ Prob(F-statistic) } & 0.000013 \\
\hline S.E. of regression & 0.015975 & & & \\
\hline
\end{tabular}

According to the results in Table 5, the short-run fluctuations in consumer prices in South Africa is determined by lagged consumer prices, lagged excess demand and the exchange rate. Wage productivity, South Africa's international position, capacity utilisation and lagged production prices were included in the ECM to fully explain the short-run dynamics of production price behavior (see Table 6).

\subsection{Diagnostic testing}

The CPI and PPI equations estimated in section 4.3 were subjected to rigorous diagnostic testing. Since all the variables in the ECM are stationary, the assumptions of classical regression analysis are fulfilled. Standard diagnostic tests can, therefore, be used to determine which variables should be included in the final specification of the ECM (Harris, 1995: 24). The diagnostic test results reported in tables 7 and 8 indicate that the equations pass all the statistical diagnostic tests. 
Table 7 Diagnostic tests of CPI error correction model

\begin{tabular}{|l|c|c|c|l|}
\hline \multicolumn{1}{|c|}{ Test } & d.f. & Test statistic & p-value & \multicolumn{1}{c|}{ Conclusion } \\
\hline Jarque-Bera & $\mathrm{JB}(2)$ & 0.57 & 0.75 & Normality \\
\hline ARCH LM & $\mathrm{nR}^{2}(1)$ & 3.74 & 0.06 & Homoscedasticity \\
\hline ARCH LM & $\mathrm{nR}^{2}(2)$ & 3.39 & 0.18 & Homoscedasticity \\
\hline White & $\mathrm{nR}^{2}(18)$ & 6.82 & 0.56 & Homoscedasticity \\
\hline $\begin{array}{l}\text { Breusch- } \\
\text { Godfrey }\end{array}$ & $\mathrm{nR}^{2}(2)$ & 1.49 & 0.47 & No serial correlation \\
\hline $\begin{array}{l}\text { Durbin- } \\
\text { Watson }\end{array}$ & $\mathrm{DW}$ & 1.77 & & No serial correlation \\
\hline Ramsey reset & $\mathrm{LR}(1)$ & 0.82 & 0.37 & No misspecification \\
\hline Ramsey reset & $\mathrm{LR}(2)$ & 0.82 & 0.37 & No misspecification \\
\hline
\end{tabular}

Table 8 Diagnostic tests of PPI error correction model

\begin{tabular}{|l|c|c|c|l||}
\hline \multicolumn{1}{|c|}{ Test } & d.f. & Test statistic & p-value & \multicolumn{1}{c|}{ Conclusion } \\
\hline Jarque-Bera & $\mathrm{JB}(2)$ & 0.63 & 0.73 & Normality \\
\hline ARCH LM & $\mathrm{nR}^{2}(1)$ & 0.28 & 0.60 & Homoscedasticity \\
\hline ARCH LM & $\mathrm{nR}^{2}(2)$ & 0.45 & 0.80 & Homoscedasticity \\
\hline White & $\mathrm{nR}^{2}(18)$ & 9.62 & 0.65 & Homoscedasticity \\
\hline $\begin{array}{l}\text { Breusch- } \\
\text { Godfrey }\end{array}$ & $\mathrm{nR}^{2}(2)$ & 3.99 & 0.14 & No serial correlation \\
\hline $\begin{array}{l}\text { Durbin- } \\
\text { Watson }\end{array}$ & $\mathrm{DW}$ & 2.49 & & No serial correlation \\
\hline Ramsey reset & $\mathrm{LR}(1)$ & 0.43 & 0.52 & No misspecification \\
\hline Ramsey reset & $\mathrm{LR}(2)$ & 1.44 & 0.59 & No misspecification \\
\hline
\end{tabular}

\subsection{Dynamic simulation: Response characteristics of the model}

The dynamic simulation of the final model yields the overall fits depicted in figures 2 and 3. These graphs illustrate that the estimated model provides a good representation of the actual consumer and production price indices of South Africa. 
Figure 2 Actual and fitted values of CPI

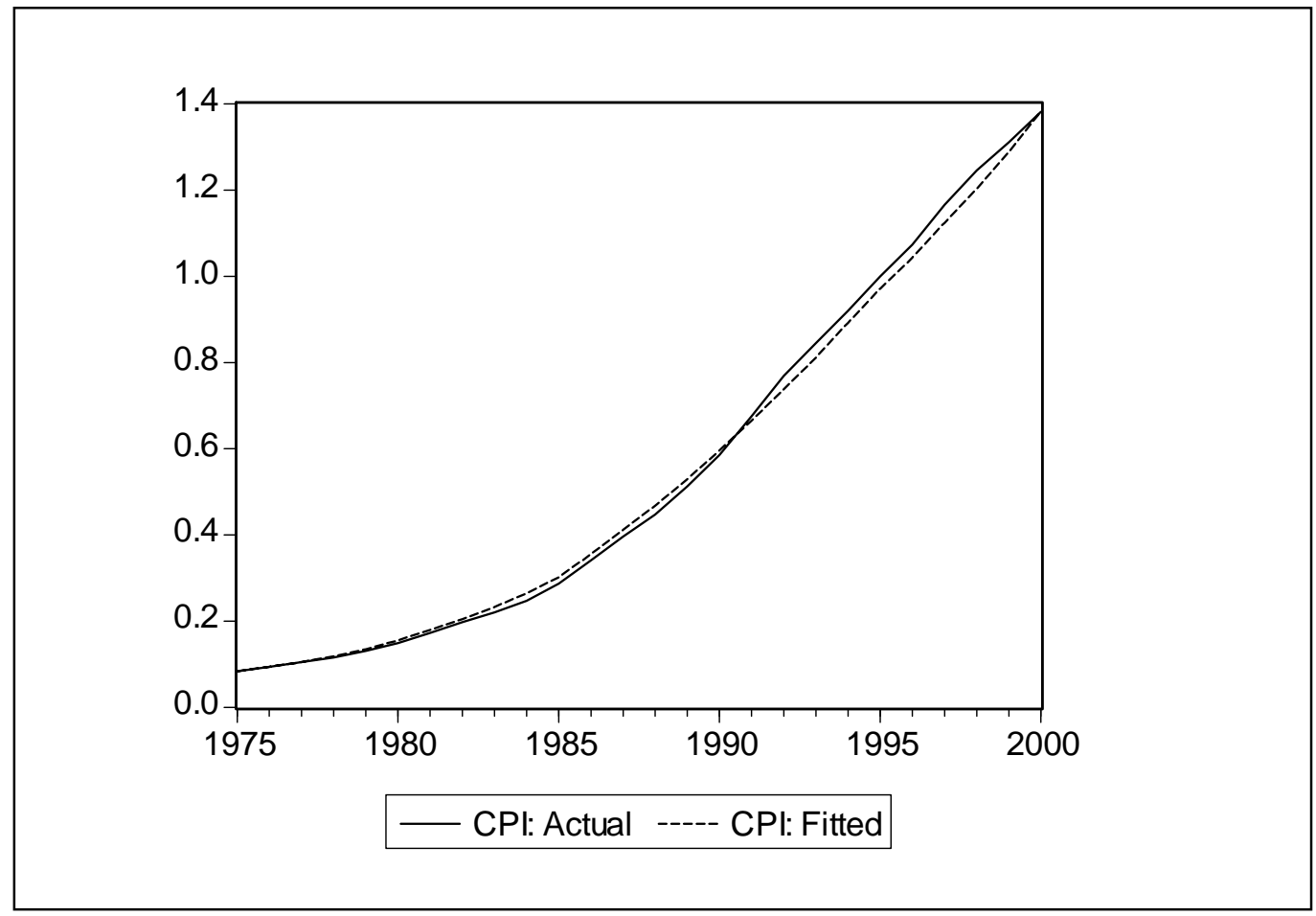

Figure 3 Actual and fitted values of PPI

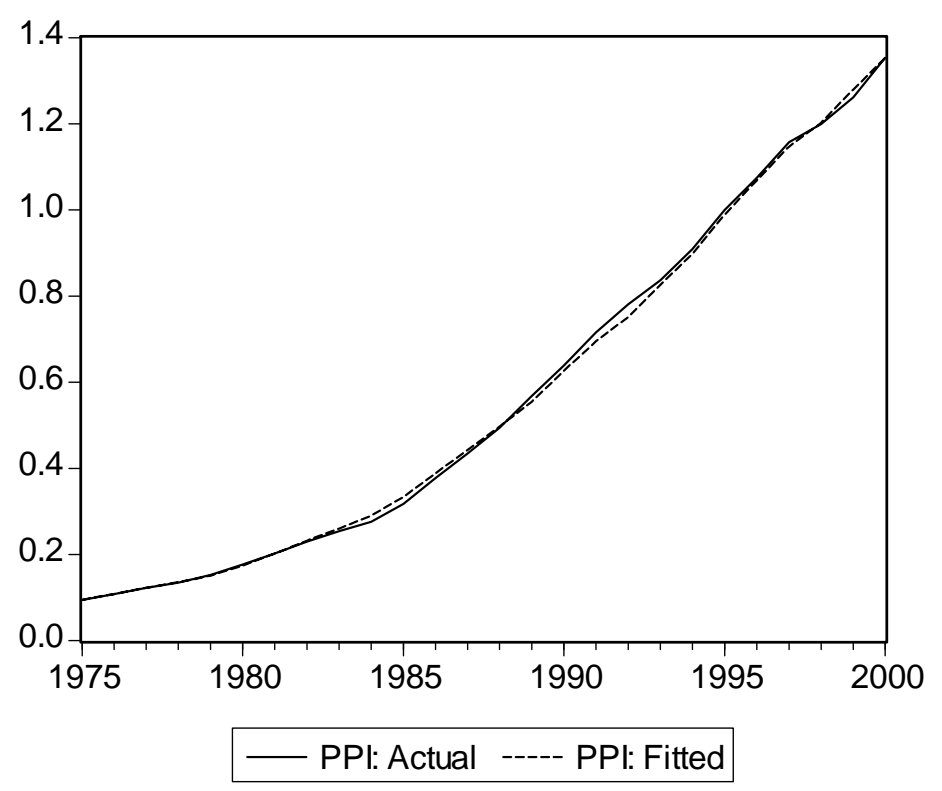


In order to analyse the response characteristics of the model, the explanatory variables have been subjected to permanent increases of 10 per cent. The resulting effects of the shocks to the user cost of capital and wage productivity on cpi and ppi are illustrated in figures 4 and 5 respectively. Shocks on the other explanatory variables yielded similar results but are omitted here for brevity. These graphs confirm that the response characteristics of the model are consistent with a priori expectations. A shock in either the user cost of capital or wage productivity causes an increase in production prices and this feeds through to consumer prices.

\section{Figure 4 Response characteristics of a shock to user cost of capital}

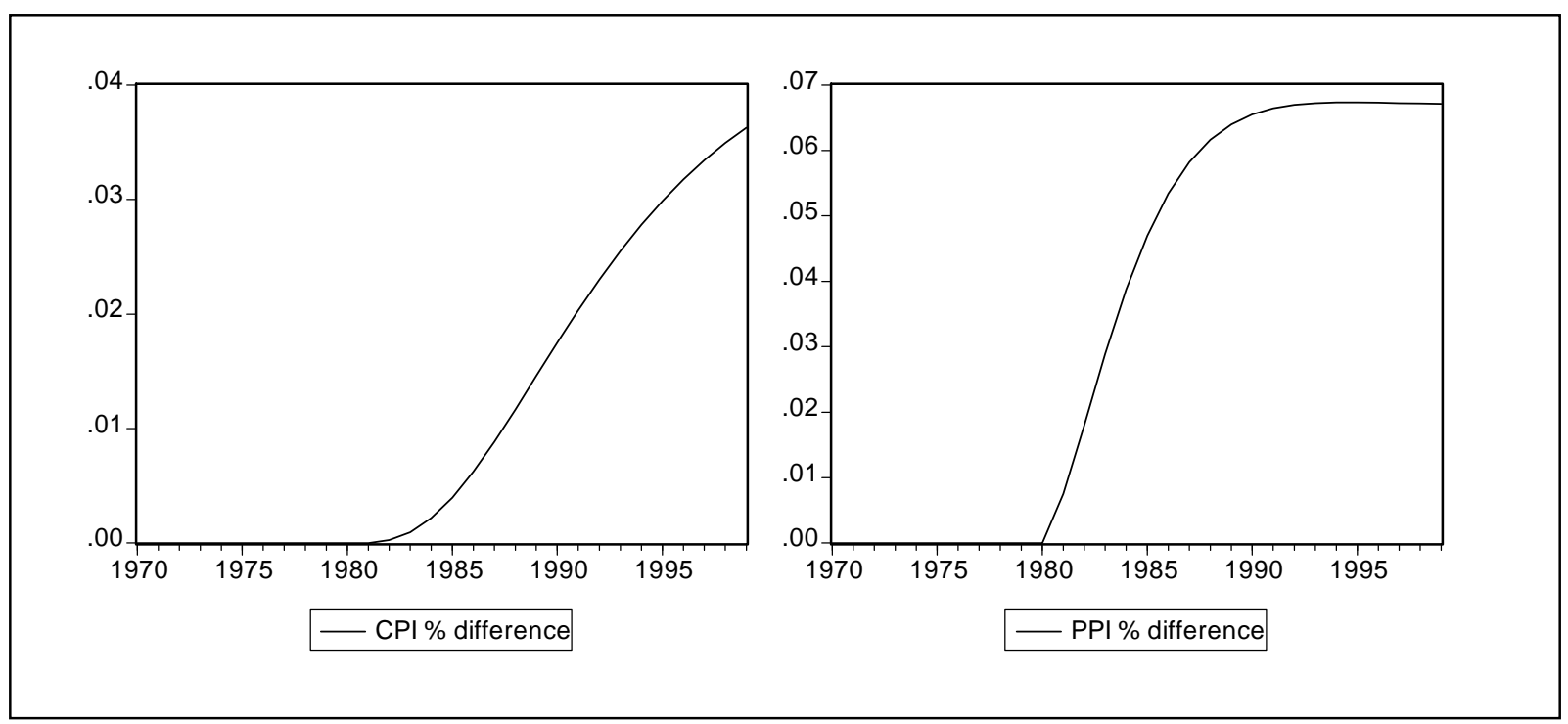

Figure 5 Response characteristics of a shock to wage productivity

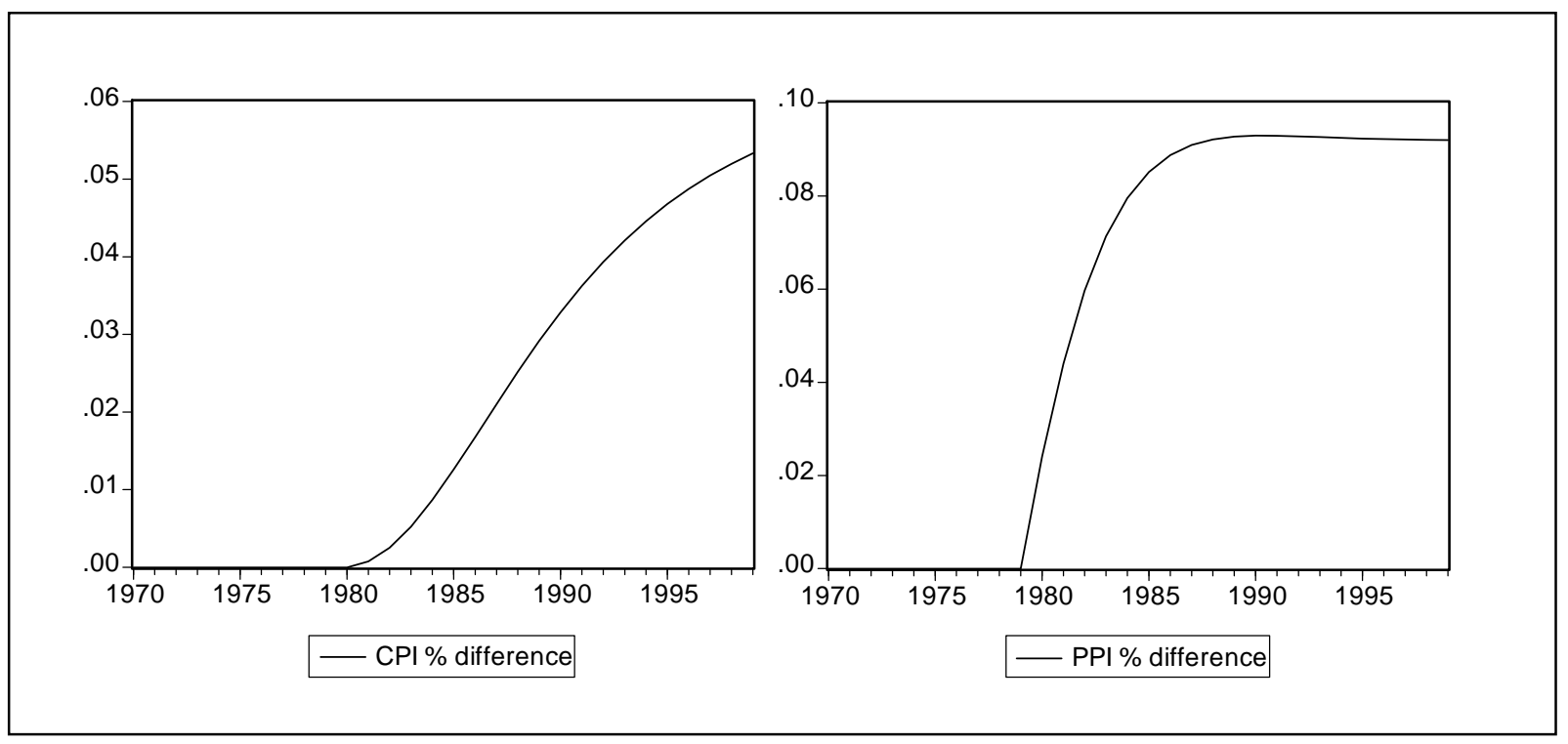




\section{POLICY IMPLICATIONS}

According to the results of the empirical estimations, consumer prices are dependent on domestic production prices and the prices of imported goods in the long run, with production prices having a bigger weight than the prices of imports. In addition, excess demand, the exchange rate and lagged consumer prices also influence consumer prices in the short run. On the other hand, domestic production prices are determined by the user cost of capital and wage productivity in the long run, with wage productivity having a bigger influence than the cost of capital. Wage productivity, South Africa's international position, capacity utilisation and lagged production prices also have an influence on the short run behavior of production prices. These results have the following policy implications:

First, monetary policy can indeed be applied successfully to manage inflation impacting on price from both a demand- and supply-side perspective. By influencing interest rates, either directly or indirectly, the user cost of capital is changed which has a direct impact on domestic production prices. Production prices in turn influences consumer prices. However, interest rates also influence total demand, which again impact on excess demand and hence consumer prices.

Second, in addition to interest rates which influence production prices through its impact on the user cost of capital, there are many other factors such as tax rates, rates of depreciation and the price of capital that also impact on the user cost of capital. These factors provide useful additional supply-side policy instruments that can be used to control inflation. It thus opens the door for fiscal policy to also impact on inflation through its corporate tax policy.

Third, based on the empirical evidence, consumer inflation is primarily driven by increases in production prices, which have a larger influence on consumer prices than the imported prices of consumer goods. In addition, wage increases, relative to productivity growth, exert more pressure on production prices, which in turn, exerts upward pressure on consumer prices. However, this does not necessarily mean that wages have to be reduced to lower inflation. It is the ratio between wages and labour productivity that influences prices, which means that a larger increase in productivity will lower the ratio of wages to productivity, driving down production price and hence, consumer prices.

Fourth, the consequences of a high degree of openness of the South African economy, represented by a set of international factors like competitiveness and openness, are large contributors to domestic inflation. This again emphasises the 
responsibility of policy authorities and politicians alike, to manage market psychology comprising political and other types of risk perceptions, the cost of doing business in South Africa, confidence in good public governance and responsible politics in general. These are necessities once the fundamentals and monetary and fiscal policy have been looked after.

\section{CONCLUSION}

In this study, models for both production and consumer prices were proposed, estimated and validated. Assuming imperfect competition in a neoclassical, profit-maximizing framework, firms set their prices as a mark-up on the unit cost of production. Extending on the Layard-Nickell framework, the pricing models estimated in this study do not assume "normal" unit costs, but incorporate the unit costs of capital in addition to labour costs. The estimation results were consistent with the theoretical specification and a priori information on the price-setting behavior of firms.

Regarding to inflation in South Africa, the estimated model suggests that (1) monetary policy can be used successfully to curb inflation. However, recent events have shown that disciplined monetary policy is a necessary, but not sufficient condition to keep inflation rates at bay. (2) There are many other policy instruments such as taxes that can also be used to address high inflation. (3) Wage increases, relative to productivity growth, exert the most pressure on production prices and (4) consumer price inflation is primarily driven by increases in the production prices, which have a larger influence on consumer prices than the imported prices of consumer goods. (5) The consequences of a high degree of openness of the South African economy, represented by a set of international factors like competitiveness and openness, are large contributors to domestic inflation.

\section{ENDNOTES}

1 Since September 2003 Dr Moolman is economist with Standard Bank.

2 CPIX inflation is headline consumer inflation excluding mortgage cost.

3 The inflation target for 2004 was afterwards amended to a range of three to six per cent.

4 The target range was made continuous in November 2003, which means that, instead of keeping average annual inflation within the target range, inflation now has to be kept within the target range every month. CPIX inflation has been within the target range since September 2003.

$5 \quad$ Reserve Bank Governor from 1981 to 1989. 
6 With the debt standstill agreement in 1985, all foreign banks ceased lending to South Africa. In reaction, the South African government prohibited South African banks from repaying foreign obligations to foreign creditors.

$7 \quad$ This approach is followed by Layard and Nickell and differs from that followed by (for example) the OECD, where the cost of capital is also included in the specification of price equations (Helliwell, 1995; Turner et al., 1996).

8 This approach was specifically followed on two occasions: "Measuring potential output in the seven major OECD countries" (Torres et al., 1989) and "Estimating potential output, output gaps and structural budget balances" (Giorno et al., 1995).

9 Wage productivity is defined as the wage rate divided by labour productivity.

\section{REFERENCES}

1 AKINBOADE, O.A., NIEDERMEIER, E.W. \& SIEBRITS, F.K. (2002) "The dynamics of inflation in South Africa: Implications for policy", South African Journal of Economics, 70: 461-84.

2 BOTHA, D.J.J. (1997) "The South African Reserve Bank and the rate of interest”, South African Journal of Economics, 65: 532-67.

3 BURDA, M. \& WYPLOSZ, C. (1993) Macroeconomics: A European Text, Oxford University Press: Oxford.

4 DU TOIT, C.B. (1999) "A supply-side model of the South African economy: critical policy implications”, Unpublished doctoral thesis, University of Pretoria: Pretoria.

5 DU TOIT, C.B. \& MOOLMAN, E. (2003) "Estimating potential output and capacity utilisation for the South African economy", South African Journal of Economics, forthcoming.

6 FOURIE, L.J., FALKENA, H.B. \& KOK, W.J. (1999) Student Guide to the South African Financial System, Oxford University Press: Cape Town.

7 HARRIS, R.I.D. (1995) Using Cointegration Analysis in Econometric Modelling, Prentice-Hall International: New Jersey.

8 HELLIWELL, J.F. (1995) Modelling the Supply Side: What are the Lessons from Recent Research on Growth and Globalization? Paper presented at Project LINK, September, Pretoria.

9 JORGENSON, D.W. (1963) "Capital theory and investment behavior", American Economic Review, 53: 247-9. 
10 LAYARD, R. \& NICKELL, S. (1985) "Unemployment, real wages and aggregate demand in Europe, Japan and the United States”, Carnegie Rochester Conference Series on Public Policy, 23: 143-202.

11 LAYARD, R. \& NICKELL, S. (1986) "Unemployment in Britain", Economica, 53: S121-69.

12 NICKELL, S. (1988) "The supply side and macroeconomic modeling”, In Bryant, R.C. et al. (eds.) Empirical Macroeconomics for Interdependent Economies, Brookings Institution: Washington: 202-21.

13 SMAL, M.M. (1998) "The cost of inflation", South African Reserve Bank: Quarterly Bulletin, September.

14 STALS, C. (1999) "The influence of international financial crises on the South African economy", Address at the $52^{\text {nd }}$ Congress of the South African Nurserymen's Association on 17 May 2000.

15 TURNER, D., RICHARDSON, P. \& RAUFFET, S. (1996) "Modelling the supply-side of the seven major OECD economies", OECD Economics Department Working Papers, No. 167, Organisation for Economic Cooperation and Development (OECD): Paris. 